\title{
PENGHAKIMAN OLEH PERS NASIONAL: SUATU KRITIK ATAS KEBEBASAN PERS DALAM PEMBERITAAN PERKARA TINDAK PIDANA KORUPSI
}

\author{
Vidya Prahassacitta \\ Business Law Department, Faculty of Humanities, BINUS University \\ Jln. Kemanggisan Ilir III No. 45, Kemanggisan - Palmerah, Jakarta 11480 \\ vidya_prahassacitta@yahoo.com
}

\begin{abstract}
The 1998 reform in Indonesia has changed freedom press in Indonesia. Now press implements libertarian model which puts freedom first instead of responsibility. Previously, press implemented soviet communist model which put responsibility first instead of freedom. Fifteen years later, press in Indonesia has become political tool by the owner of the press company who has high position in political party participating in the 2014 election. This reflects on the disproportional news regarding corruption cases conducted by the government officer or parliament member from the contender party. Such news delivers not only facts but also misleading opinions to the society which creates trial by the press. In fact, presumption of innocent principle is a foundation for press reporting news as stipulated in Law No. 40 Year 1999 concerning Press and Journalistic Code of Conduct. In libertarian press there are always borders but such borders are not effective since the freedom of press in Indonesia is powerful. Article used qualitative and library research with secondary sources of law to gain a solution to this problem. Therefore, Press Board should maximize its function in supervising the implementation of presumption of innocent principle and to raise society awareness regarding the law supremacy. In the end, to fulfill press social responsibility, a press profession court shall be established to keep press independency.
\end{abstract}

Keywords: freedom of press, presumption of innocent principle, trial by the press

\begin{abstract}
ABSTRAK
Pascareformasi 1998 membawa dampak besar pada kebebasan pers. Pers nasional menganut model libertarian yang bebas dan menomorduakan tanggung jawab, yang sebelumnya menganut model soviet komunis yang lebih menitikberatkan pada tanggung jawab ketimbang kebebasan. Kini lima belas tahun setelah reformasi, pers nasional telah menjadi corong dan alat politik bagi pemilik perusahaan pers yang juga merupakan petinggi partai politik yang menjadi peserta pemilu 2014. Hal tersebut terlihat dari tidak proporsionalnya pemberitaan mengenai perkara tindak pidana korupsi yang melibatkan pejabat yang berkuasa atau anggota Dewan Perwakilan Rakyat dari partai pesaing. Pemberitaan-pemberitaan tersebut tidak hanya menyampaikan fakta saja tetapi juga membuat opini yang mengiring masyarakat untuk memvonis tersangka, terdakwa, atau kelompok tertentu bersalah mesikpun pengadilan belum menutuskan hal tersebut. Pemberitaan tersebut merupakan pengabaian dari asas praduga tidak bersalah yang seharusnya menjadi pedoman bagi pers nasional sebagaimana dimaksud dalam Undang-Undang No. 40 Tahun 1999 tentang Pers dan Kode Etik Jurnalistik. Hal ini tentu melanggar hak-hak dasar tersangka dan terdakwa. Dalam libertarian pers selalu terdapat rambu-rambu hukum, namun terlalu merdekanya pers di Indonesia menyebabkan rambu-rambu hukum yang ada menjadi tidak efektif. Dengan menggunakan penelitian kualitatif dan kepustakaan dengan mendasarkan pada sumber hukum sekunder maka penelitian hukum ini dilakukan untuk memperoleh solusi atas permasalahan ini. Melalui penelitian ini diketahui bahwa diperlukan peran maksimal dari Dewan Pers untuk melakukan pengawasan terhadap pelaksanaan dari asas praduga tidak bersalah. Dewan Pers juga harus memaksimalkan perannya untuk mendidik pers nasional akan tanggung jawab sosial kepada masyarakat dengan memberikan pemberitaan yang tidak menghakimi dan cerdas.
\end{abstract}

Kata kunci: kebebasan pers, asas praduga tidak bersalah, pengakiman oleh pers 


\section{PENDAHULUAN}

Upaya pemberantasan tindak pidana korupsi yang dilakukan oleh lembaga penegak hukum di Indonesia memang menjadi sorotan masyarakat luas. Salah satu lembaga yang selalu disorot kinerjanya adalah Komisi Pemberantasan Korupsi (KPK) yang merupakan pintu terdepan dalam upaya pemberantasan korupsi di Indonesia. Sejak KPK berdiri, statistik perkara tindak pidana korupsi yang telah ditangani KPK mulai dari penyelidikan, penyidikan, penuntutan sampai keputusan Pengadilan Tindak Pidana Korupsi pada Pengadilan Negeri Jakarta Pusat di tingkat pengadilan pertama maupun pada tingkat banding di Pengadilan Tinggi DKI Jakarta serta pada tingkat kasasi di Mahkamah Agung terus mengalami peningkatan setiap tahunnya. Berdasarkan statistik dari Anti-Corruption Clearing House yang merupakan portal informasi yang dikelola dan dikembangkan oleh KPK pada akhir Oktober 2013 jumlah perkara yang sedang dan telah selesai diproses oleh KPK mencapai 578 perkara. Angka ini jauh lebih besar jika dibandingkan dengan jumlah perkara yang sedang dan telah selesai diproses oleh KPK pada2004 yang hanya sebanyak 240 perkara.

Tabel 1 Tabulasi Data Penanganan Korupsi (oleh KPK) Tahun 2004-2013

(31 Oktober 2013)

\begin{tabular}{lccccccccccc} 
Penindakan & $\mathbf{2 0 0 4}$ & $\mathbf{2 0 0 5}$ & $\mathbf{2 0 0 6}$ & $\mathbf{2 0 0 7}$ & $\mathbf{2 0 0 8}$ & $\mathbf{2 0 0 9}$ & $\mathbf{2 0 1 0}$ & $\mathbf{2 0 1 1}$ & $\mathbf{2 0 1 2}$ & $\mathbf{2 0 1 3}$ & Jumlah \\
\hline Penyelidikan & 23 & 29 & 36 & 70 & 70 & 67 & 54 & 78 & 77 & 74 & 578 \\
Penyidikan & 2 & 19 & 27 & 24 & 47 & 37 & 40 & 39 & 48 & 59 & 342 \\
Penuntutan & 2 & 17 & 23 & 19 & 35 & 32 & 32 & 40 & 36 & 31 & 267 \\
Inkracht & 0 & 5 & 17 & 23 & 23 & 39 & 34 & 34 & 28 & 25 & 228 \\
Eksekusi & 0 & 4 & 13 & 23 & 24 & 37 & 36 & 35 & 32 & 36 & 240 \\
\hline
\end{tabular}

Dari perkara-perkara yang ditangani oleh KPK tersebut terdapat beberapa perkara besar. Memang secara yuridis berdasarkan ketentuan Pasal 11 Undang-Undang Nomor 30 Tahun 2002 tentang Komisi Pemberantasan Korupsi secara tegas dinyatakan bahwa KPK berwenang untuk melakukan penyelidikan, penyidikan, dan penuntutan tindak pidana korupsi yang melibatkan aparat penegak hukum, penyelenggara negara, dan orang lain yang ada kaitannya dengan tindak pidana korupsi yang dilakukan oleh aparat penegak hukum atau penyelenggara negara, perkara tindak pidana korupsi yang mendapat perhatian yang meresahkan masyarakat, serta tindak pidana yang menyangkut kerugian negara paling sedikit 1 milyar rupiah. Perkara-perkara besar tersebut umumnya merupakan tindak pidana korupsi yang melibatkan anggota Dewan Perwakilan Rakyat (DPR), pejabat tinggi pada suatu departemen atau kementerian maupun ketua lembaga tinggi negara.

Perkara-perkara besar tersebut tentunya menarik perhatian masyarakat sehingga menjadi pemberitaan di media massa, baik media cetak, elektronik maupun media cyber. Pemberitaan tersebut tidak saja menjadi headline yang menghiasi dan mendominasi pemberitaan di media massa. Lebih dari itu media massa juga berlomba-lomba untuk mengulas dan melakukan investigasi atas perkara-perkara tersebut. Selain itu media elektronik juga sering kali menanyangkan acara dialog yang mengulas suatu perkara tindak pidana korupsi dengan menghadirkan berbagai narasumber.

Jika diperhatikan, penyampaian pemberitaan mengenai perkara-perkara tindak pidana korupsi tersebut mengalami perubahan. Cara penyampaian dan materi yang disampaikanmedia massa terutama media cetak dan media elektronik pascareformasi lebih luas dan tajam bahasannya. Tentunya hal ini sangat baik karena pers diberi kebebasan untuk menyampaikan pemberitaan kepada masyarakat sebagai bagian dari semangat dari pemberantasan korupsi. Namun di sisi lain jika dicermati secara mendalam, materi dan penyampaian pemberitaan perkara-perkara tindak pidana korupsi tersebut telah melanggar hak-hak dasar dari tersangka atau terdakwa tindak pidana korupsi. Banyak pemberitaan yang menimbulkan dan menggiring opini publik tentang perkara tindak pidana korupsi yang mulai 
disidik oleh KPK. Hal ini telah menyudutkan para tersangka atau terdakwa tindak pidana korupsi atau kelompok tertentu, dan bahkan yang terjadi adalah para tersangka, terdakwa, ataupun pihak-pihak terkait lainnya seolah-olah telah diadili atau dinyatakan bersalah oleh masyarakat terlebih dahulu sebelum mereka benar-benar diadili atau dinyatakan bersalah oleh putusan pengadilan tindak pidana korupsi. Terlebih pemberitaan tersebut makin gencar dilakukan menjelang Pemilihan Umum 2014. Pemberitaan tersebut dilakukan terhadap tindak pidana korupsi yang dilakukan oleh pejabat pemerintah incumbent maupun oleh anggota DPR dari partai tertentu. Hal ini terutama dilakukan oleh media massa terutama media elektronik yang dimiliki oleh salah satu petinggi partai yang mengikuti Pemilihan Umum 2014.

Memang pascareformasi terjadi pergeseran dalam hukum pers di Indonesia. Pascareformasi pers nasional menganut prinsip kemerdekaan pers sebagaimana diatur dalam Undang-Undang No. 40 Tahun 1999 tentang Pers (UU No. 40 Tahun 1999) yang menjadi payung hukum bagi seluruh kegiatan pers di Indonesia. Dalam hal ini, tidak diperbolehkan dilakukan sensor dan pemberedelan terhadap semua produk pers. Meskipun demikian, tetap terdapat rambu-rambu hukum yang harus ditaati oleh pers dalam melaksanakan pemberitaannya. Hal tersebut menarik untuk dibahas, yaitu tentang ramburambu hukum bagi pers dalam melakukan kegiatannya terkait penyampaian pemberitaan mengenai perkara-perkara tindak pidana korupsi. Lebih lanjut, menarik pula untuk dibahas apakah rambu-rambu hukum tersebut efektif untuk melindungi kepentingan hukum tersangka maupun terpidana.

Dalam kerangka hukum pers dikenal konsep freedom of expression yang mencangkup konsep freedom of press dan freedom of speech. Pers dalam arti sempit dikaitkan dengan konsep freedom of press. Pers dalam pengertian sempit diartikan sebagai bentuk penyiaran pikiran, gagasan, ataupun berita melalui media tertulis. Sedangkan pers dalam arti luas diartikan sebagai komunikasi massa dengan menyampaikan pikiran dan perasaan seseorang baik dengan media tertulis maupun dengan media lisan. Dengan demikian kebebasan pers dalam arti luas terkait dengan konsep freedom of speech. Cakupan pengertian pers yang melingkupi kedua media tersebut yaitu media tertulis dan media lisan telah ditegaskan The Commission on the Freedom of Press yang menyatakan: "It will be undestood that we are using the term "press" to include all means of communicating to public news and opinions, emotions and beliefs, whether by newspapers, magazine, or book, by radio broadcast, by television or films.”(Adji, 1977)

Konsep yang kedua adalah konsep pers yang bebas dan bertanggungjawab atau a free and responsible press. Konsep tersebutadalah konsep yang dikemukakan oleh the Commission on Freedom of the Press. Konsep ini merupakan konsep yang bersifat universal.Dalam konsep ini terdapat dua hal yang menjadi fondasi, yaitu kebebasan atau freedom dan tanggung jawab atau responsible.Di negara sosial-komunis penekanan pada pers yang bertanggungjawab dan bebasadalah lebih kepada tanggungjawab darikebebasan.Substansi pemberitaan lebih diarahkan pada pertanggungjawaban pers itu sendiri melalui sensor dan pemberedelan.Kebebasan pers menjadi pelengkap saja.Berbeda dengan konsep negara barat,kebebasan memiliki fungsi yang pertama dan tanggung jawab menjadi pendukung.Dalam konsep ini sensor dan pemberedelan menjadi sesuatu yang terlarang, namun pembatasan represif berupa peraturan-peraturan pidana yang mengandung delik-delik pers menjadi sesuatu yang sah dan konstitusional(Seno Adji, 2008).

\section{METODE}

Penelitian ini merupakan penelitian kualitatif yang mencakup kegiatan penyusunan dan perancangan penelitian, pengumpulan dan pengolahan data, serta analisis data yang terkumpul untuk kemudian disusun dalam suatu laporan penelitian. Data yang digunakan dalam penelitian ini merupakan data yang bersumber dari data sekunder, yaitu data yang diperoleh dari metode penelitian 
kepustakaan dengan menelaah bahan-bahan kepustakaan atau dengan melakukan studi dokumen. Data sekunder yang digunakan dalam penelitian ini adalah sebagai berikut.

Pertama, bahan hukum primer, yaitu bahan-bahan yang isinya mempunyai kekuatan mengikat pada masyarakat dan terdiri dari norma-norma dasar seperti undang-undang dan peraturan perundangundangan lainnya. Kedua, bahan hukum sekunder, yaitu bahan-bahan yang memberikan informasi atau hal-hal yang berkaitan dengan isi bahan primer dan implementasinya, antara lain buku, majalah hukum, jurnal hukum maupun nonhukum baik dari jurnal nasional maupun jurnal internasional, hasil karya ilmiah penelitian yang ditulis dalam makalah seminar, tesis, disertasi yang isinya dapat dipertanggungjawabkan. Ketiga, bahan hukum tersier, yaitu bahan-bahan yang memberikan petunjuk maupun penjelasan terhadap bahan hukum primer dan sekunder seperti pedoman yang dikeluarkan oleh Dewan Pers Nasional, artikel dari website, pemberitaan dari media massa baik cetak, elektronik, dan cyber maupun peraturan yang isinya dapat dipertanggungjawabkan.

Sebagai suatu penelitian hukum, penelitian ini juga merupakan penelitian normatif hukum dengan menggunakan pendekatan yuridis normatif. Penelitian berdasarkan pada norma-norma hukum dalam peraturan perundang-undangan terkait yang ditekankan pada analisis masalah hukum dengan menarik asas-asas hukum dan melakukan sinkronisasi pada peraturan perundang-undangan.

\section{HASIL DAN PEMBAHASAN}

\section{Pers Libertarian di Indonesia Pascaera Reformasi}

Pada era orde baru kebebasan pers cenderung dikekang. Pasal 4 dan 5 Ayat (1) UndangUndang No. 11 Tahun 1966 tentang Ketentuan-Ketentuan Pokok Pers memang secara tegas menyatakan bahwa pers nasional tidak dikenakan sensor dan pemberedelan serta kebebasan pers merupakan hak asasi warga negara. Namun Undang-Undang No. 21 Tahun 1982 tentang Perubahan kedua Undang-Undang No. 11 Tahun 1966 tentang Ketentuan-Ketentuan Pokok Pers sebagaimana telah diubah dengan Undang-Undang No. 4 Tahun 1967 memberikan pengekangan dalam bentuk administratif. Pengekangan dalam bentuk administratif yang dimaksud adalah setiap penyelenggara penerbitan pers yang dilaksanakan oleh perusahaan pers harus memiliki Surat Izin Usaha Penerbitan Pers (SIUPP). SIUPP inilah yang dapat diartikan sebagai bentuk sensor bagi kebebasan pers. Bahkan SIUPP ini dijadikan sarana pemberedelan terhadap penerbitan pers ketika pada 1994 pemerintah melalui Surat Keputusan Menteri Penerangan Republik Indonesia Nomor 123, 124, dan 125, tanggal 21 Juni 1994 yang mencabut SIUPP terhadap majalah Tempo, Editor, dan Detik (Adji \& Adji, 1995).

Begitu pula dengan kebebasan pers dalam arti luas yang mencakup komunikasi massa dengan menyampaikan pikiran dan perasaan seorang baik dengan media tertulis maupun dengan media lisan. Pada era orde baru freedom of speech dibatasi melalui Undang-Undang No. 24 Tahun 1997 tentang Penyiaran. Dalam undang-undang tersebut diperlukan adanya izin penyelenggaraan penyiaran untuk melakukan komunikasi massa melalui media lisan. Materi yang akan disiarkan oleh media elektronik tersebut sangat dibatasi dan diatur. Pemerintah orde baru pun membentuk Badan Pertimbangan dan Pengendalian Penyiaran Nasional (BP3N) yang merupakan lembaga yang dibentuk khusus oleh pemerintah untuk melakukan pembinaan dan pengendalian terhadap kegiatan penyiaran di Indonesia. Salah satu kewenangan BP3N adalah memberikan rekomendasi dalam penerbitan, perpanjangan, penangguhan, dan pencabutan izin penyelenggaran penyiaran. Hal ini menunjukan bahwa sensor dan pemberdelan pada masa orde baru tidak hanya terdapat media cetak tetapi juga media elektronik.

Pembatasan terhadap freedom of expression tersebut seperti model pers soviet komunis. Dalam hal ini, meskipun pihak swasta diberi kesempatan dan kebebasan untuk melakukan kegiatan 
pers, pada kenyataannya penerbitan dan penyiaran pers didominasi oleh partai komunis. Jaminan atas freedom of pers dan freedom of speech pada kenyatannya didahului dengan tindakan-tindakan penyensoran sehingga merupakan aksesori belaka (Adji, 2008). Begitu pula kebebasan pers di Indonesia pada masa orde baru, pemerintah memegang kendali penuh atas kegiatan penerbitan dan penyiaran pers melalui penyensoran dan pembedelan atas media cetak dan media elektronik, sehingga istilah kebebasan pers yang tanpa sensor dan pemberdelan hanyalah slogan semata.

Keadaan tersebut berubah seratus delapan puluh derajat setelah orde baru tumbang. Pada era reformasi keran kebebasan berekspresi dibuka secara lebar. UU No. 40 Tahun 1999 disahkan dan mencabut Undang-Undang No. 11 Tahun 1966 tentang Ketentuan-Ketentuan Pokok Pers sebagaimana telah diubah terakhir kalinya dengan Undang-Undang No. 21 Tahun 1982. Dalam UU No. 40 Tahun 1999 dianut kemerdekaan pers yang bebas dari sensor dan pemberdelan. Demikian juga dengan diundangkannya Undang-Undang No. 32 Tahun 2002 tentang Penyiaran (UU No. 32 Tahun 2002) yang menggantikan Undang-Undang No. 24 Tahun 1997. Meskipun dalam UU No. 32 Tahun 2002 masih disyaratkan adanya izin penyelenggaraan penyiaran, izin tersebut hanya izin administrasi saja yang bukan merupakan tindakan penyensoran. Selain itu keberadaan BP3N juga sudah ditiadakan dan digantikan dengan Komisi Penyiaran Indonesia (KPI) yang merupakan lembaga independen yang mengatur mengenai penyelenggaraan penyiaran di Indonesia.

Pascareformasi pers di Indonesia bergerak dari pers yang bertanggung jawab dan bebas menjadi pers yang bebas dan bertanggungjawab. Dalam hal ini kebebasan pers menjadi hal yang utama dengan tanggung jawab menjadi pelengkapnya. Pers memiliki kebebasan yang seolah-olah absolut dengan adanya hak tolak sebagaimana diatur dalam Pasal 4 ayat (4) UU No. 40 Tahun 1999. Dalam penjelasan Pasal 4 ayat (4) UU No. 40 Tahun 1999 konsep hak tolak yaitu hak bagi wartawan untuk tidak menyebutkan identitas narasumbernya jika wartawan dimintai keterangan oleh penyidik maupun di muka pengadilan, yang hanya dapat dikecualikan untuk kepentingan negara dan kepentingan umum yang dinyatakan di muka pengadilan. Konsep hak tolak ini sama seperti konsep privilege right dalam aliran libertarian.

Kebebasan berekspresi tersebut pun tidak hanya sebatas slogan di undang-undang saja tetapi juga dapat dilihat dari maraknya pemberitaan yang disajikan beragam media cetak dan elektronik. Jika dahulu pada masa orde baru materi pemberitaan diarahkan kepada pemberitaaan yang pro terhadap kebijakan pemerintah, dan jika tidak, akan dikenakan pemberedelan. Berbeda dengan era reformasi, materi pemberitaan menyuarakan kebijakan pemerintah maupun oposisi. Namun hal ini pun menimbulkan masalah, karena jika diperhatikan, materi pemberitaan yang ada dewasa ini kadang kala bukan pemberitaan yang berimbang proposinya melainkan dibuat cenderung untuk kepentingan salah satu pihak, terutama pihak pemilik media cetak maupun media elektronik yang merupakan pendiri atau petinggi suatu partai politik.

Memerhatikanpemberitaan mengenai perkara-perkara tindak pidana korupsi yang melibatkan anggota DPR dari partai tertentu, pejabat tinggi dari suatu departemen atau kementerian maupun ketua lembaga tinggi negara, jumlah pemberitaan yang memberikan materi pemberitaan yang berimbang tanpa menyudutkan salah satu pihaktentu tidak banyak. Bukan hanya perkara-perkara tersebut menarik perhatian masyarakat banyak, melainkan juga kadang kala hal tersebut dijadikan alat oleh pemilik media cetak dan elektronik yang merupakan pendiri atau peninggi suatu partai politik untuk membentuk opini publik menjelang pemilihan umum 2014.

Perkembangan pers Indonesia pascaera reformasitelah berubah drastis dari perkembangan pers soviet komunis menjadi pers libertarian. Dalam kerangka pers libertarian tersebut masyarakat diberi kebebasan yang sebebas-bebasnya untuk berbicara dan bereksprsi sehingga peran pemerintah dalam pengawasan pemberitaan diperkecil dan jika perlu dihilangkan. Dengan demikian setiap pernyataan, pendapat maupun ekspresi dari seseorang maupun golongan adalah bebas tanpa batas yang artinya segala sesuatu yang berkaitan dengan akibatnya menjadi soal dan wewenang badan peradilan (Adji, 
2008). Pers di Indonesia dewasa ini begitu merdeka bahkan Indonesia merupakan negara yang menganut sistem yang paling bebas di negara-negara Asia Tenggara (Steele, 2013). Terlalu bebasnya pers di Indonesia sehingga seolah-olah tidak ada suatu lembaga apapun yang dapat menyentuh kebebasan pers tersebut.

\section{Kemerdekaan Pers yang Menuju Penghakiman oleh Pers}

Semangat pemberantasan tindak pidana korupsi menjadi alasan maraknya pemberitaan tentang penanganan perkara tindak pidana korupsi. Hal ini terlihat mulai dari pengungkapan secara terangterangan nama dan wajah tersangka atau terdakwa tindak pidana korupsi dalam media massa. Dalam pandangan publik untuk suatu perkara seperti tindak pidana korupsi yang mendapat perhatian dan perbuatan yang amat tercela dalam masyarakat, pemuatan identitas dan wajah tersangka atau terdakwa telah memberikan kepuasan masyarakat terlepasdari pelakunya dikenal oleh masyarakat atau tidak (Loqman, 2010).

Lebih lanjut pemberitaan perkara tindak pidana korupsi tersebut tidak hanya pemberitaan biasa tetapi juga diikuti dengan investigasi dan dialogdengan narasumber. Tentu hal tersebut sah-sah saja selama pemberitaan tersebut dilakukan secara proporsional dan tidak menciptakan dan menggiring opini masyarakat yang memvonis seorang tersangka atau terdakwa bersalah meskipun pengadilan tindak pidana korupsi belum menjatuhkan vonis terhadap tersangka atau terdakwa tersebut.

Salah satu perkara yang menunjukan kemerdekaan pers tanpa memerhatikan proporsionalitas pemberitaan adalah dalam perkara tindak pidana korupsikuota impor daging sapi dengan terdakwa Lutfi Hasan Ishaaq. Pers begitu heboh dan bersemangat saat pembacaan dakwaan oleh jaksa penuntut umum namun tidak berimbang pada peliputan dan pemberitaan ketika tim kuasa hukum terdakwa membacakan eksepsi. Begitu pula pada saat salah satu saksi kunci perkara tindak pidana korupsi kuota impor daging sapi dengan terdakwa Lutfi Hasan Ishaaq, Ahmad Fathanah, bersaksi, pers pun memberitakannya secara besar-besaran dengan siaran langsung. Namun begitu kesaksian Ahmad Fathanah tidak sesuai yang diharapkan, siaran langsung pun mendadak dihentikan. Maka tidak heran jika Lutfi Hasan Ishaaq menyatakan bahwa dirinya telah diadili oleh pers. Tentunya perkara tindak pidana korupsi kuota impor daging sapi dengan terdakwa Lutfi Hasan Ishaaq hanya salah satu contoh saja.

Di Indonesia pers diberi kebebasan dan ruang yang luas untuk melakukan pemberitaan mengenai suatu perkara tindak pidana korupsi. Keleluasaan tersebut sejak dari proses penyelidikan sampai kepada proses persidangan. Tentu masyarakat sudah terbiasa melihat wawancara dengan juru bicara maupun pimpinan KPK terhadap suatu perkara tindak pidana korupsi yang masih dalam tahap penyelidikan atau penyidikan. Pada tahap selanjutnya pers juga sering melakukan investigasi dan wawancara maupun dialog terhadap narasumber atas keterangan saksi-saksi yang disampaikan dimuka pengadilan. Hal ini berbeda dengan beberapa negara yang membatasi ruang bagi pers untuk dapat melakukan pemberitaan terhadap perkara tindak pidana korupsi. Walaupun dalam wawancara maupun dialog tersebut dihadirkan narasumber dari pihak tersangka atau terdakwa, kadang kala kesempatan yang diberikan tidaklah berimbang, bahkan terkadang pernyataan narasumber tersebut dipotong oleh pembawa acara sebelum narasumber tersebut benar-benar selesai menyampaikan seluruh pernyataan dan informasinya. Tidak jarang media massa dijadikan sarana bagi pihak yang berkepentingan untuk membangun opini publik atas suatu perkara tindak pidana korupsi yang masih belum mulai atau selesai proses persidangannya.

Sadar atau tidak, kebebasan pers tersebuttelah disalahgunakan oleh pers di Indonesia. Pers nasional menjadi tidak netral lagi dalam melakukan pemberitaan dengan menghadirkan pemberitaan yang tidak proporsional dan telah mengadili para tersangka atau terdakwa melalui pemberitaanpemberitaan yang dapat menimbulkan opini publik. Bahkan pers nasional telah dijadikan alat politik 
untuk menjatuhkan lawan politik oleh pihak yang berkepentingan melalui pemberitaan tentang perkara tindak pidana korupsi tersebut. Hal ini terutama dilakukan oleh perusahaan pers yang dimiliki oleh petinggi partai politik yang menjadi peserta pemilihan umum 2014.

Sebenarnya Pasal 5 ayat (1) UU No. 40 Tahun 1999 telah mengatur kewajiban pers nasional untuk memberitakan suatu peristiwa dan opini yang didasarkan pada asas praduga tidak bersalah. Bahkan penjelasan Pasal 5 ayat (1) UU No. 40 Tahun 1999 telah memberikan kewajiban bagi pers nasional untuk menyiarkan informasi yang tidak menghakimi atau membuat kesimpulan kesalahan seseorang, terutama untuk perkara yang masih dalam proses peradilan, pers nasional harus dapat mengakomodasikan kepentingan semua pihak yang terkait dalam pemberitaan tersebut.

Penerapan asas praduga tidak bersalah dalam pers berbeda dengan dalam hukum acara pidana yang menyatakan bahwa seseorang belum dan/atau tidak boleh dinyatakan bersalah sampai ada putusan pengadilan yang berkekuatan hukum tetap. Dalam pers asas praduga tidak bersalah diartikan sebagai larangan untuk membuat pemberitaan yang menghakimi, yang tidak hanya terbatas pada pemberitaan yang sudah menyangkut proses penyidikan sampai dengan persidangan tetapi juga mencakup pada semua pemberitaan. Terjadi pergeseran arti asas praduga tidak bersalah dari sekadar menyatakan seseorang bersalah atau tidak bersalah dalam suatu proses penyelidikan sampai dengan persidangan namun lebih luas dengan adanya larangan terhadap penghakiman semua pemberitaan yang kebenarannya belum terbukti, baik menurut proses hukum maupun dari hasil pengecekan pers sendiri. Selain itu dalam pers walaupun pengadilan sudah memvonis seorang terdakwa bersalah secara hukum, pers tetap tidak diberi hak untuk menyatakan orang itu bersalah atau tidak bersalah. Pers hanya berwenang untuk menyampaikan fakta yang menurut pengadilan menyatakan terdakwa tersebut bersalah (Sukardi, 2010).

Pertanyaannya adalah tentang upaya hokum yang dapat dilakukan oleh tersangka atau terdakwa sebagai pihak yang dirugikan akibat pemberitaan yang tidak proporsional dan menghakimi kesalahan tersangka atau terdakwa tersebut. Dalam kerangka hukum pers, Pasal 5 ayat (2) UU No. 40 Tahun 1999 telah memberikan lembaga hak jawab untuk mengatasi pemberitaan pers yang tidak proporsional tersebut. Hak jawab merupakan perimbangan dari hak tolak. Hak jawab dimaksudkan untuk melakukan reaksi terhadap suatu pemberitaan yang dipandang kurang benar. Kenyataannya hak jawab tersebut jarang atau bahkan tidak pernah digunakan. Keberadaan lembaga hak jawab dianggap tidak efektif. Hal tersebut disebabkan efektivitas hak jawab bergantung pada isi suatu pemberitaan dengan akibat dari isi pemberitaan tersebut yang dianggap benar atau tidak. Akan menjadi efektif jika isi pemberitaan yang tidak benar tersebut masih dianggap sebanding dengan akibat pemberitaannya. Sebaliknya jika berita tersebut sudah merupakan berita yang misleading conclusion dan prejudicial sifatnya, hak jawab menjadi tidak efektif (Adji, 2001).

Jika demikian, upaya hukum perdata dapat menjadi pilihan. Gugatan perdata perbuatan melawan hukum terkait penghinaan Pasal 1372 Kitab Undang-Undang Hukum Perdata merupakan salah satu batasan atas kebebasan pers di Indonesia yang dapat ditempuh. Salah satu perkara perdata terkait dengan hal tersebut adalah gugatan H.M. Soeharto kepada majalah Time selaku Tergugat I, Donald Marrison, editor Majalah Time Asia, selaku Tergugat II, John Colmey, Davit Liebhold, Lisa Rose Weaver, Zamira Lubis, dan Jason Tejasukmana yang masing-masing menjadi Tergugat III sampai dengan Tergugat VII. Gugatan tersebut diajukan mengenai tulisan dan gambar yang bersifat tendensius dalam Majalah Time terbitan Edisi Asia tanggal 24 Mei 1999 Vol. 153 No. 2. Tulisan dan gambar yang dimuat oleh majalah Time tersebut bukan bertujuan untuk memberikan informasi bagi kepentingan umum melainkan lebih pada penghinaan yang bersifat tendensius, insuiatif, provokatif, dan tidak mencerminkan suatu pers yang bebas dan bertanggung jawab (Adji, 2001). Mahkamah Agung melalui Putusannya No. 3215 K/PDT/2001 tanggal 28 Agustus 2007 telah menerima permohonan Kasasi dari H.M.Soeharto dan membatalkan Putusan Pengadilan Tinggi Jakarta No. 551/PDT/2000/PT.DKI tanggal 16 Maret 2001 yang menguatkan Putusan Pengadilan Negeri Jakarta Pusat No. 338/PDT.G/1999.JKT.PST. tanggal 6 Juni 2000 dan mengadili sendiri dengan menyatakan 
bahwa para tergugat bersalah melakukan perbuatan melawan hukum, menghukum para tergugat untuk meminta maaf tentang H. M. Soeharto yang dimuat dalam majalah Time tersebut dalam beberapa surat kabar nasional dan internasional, serta menghukum para tergugat untuk membayar ganti rugi sebesar Rp.1.000.000.000.000,- (satu triliun rupiah) secara tanggung renteng.

Selain upaya hukum perdata, upaya hukum melalui hukum pidana dapat ditempuh sebagai suatu upaya ultimum remedium. Dalam kerangka hukum pidana batasan atas kebebasan pers adalah melalui delik-delik pers. Delik-delik tersebut terkait libel atau yang dalam bahasa Indonesianya dapat disepadankan dengan pencemaran nama baik dan slander yang disepadankan dengan fitnah dan defamation yang disepadankan dengan penghinaan. Delik pers berbeda dengan kejahatan dengan percetakan. Delik pers merupakan tindak pidana yang dilakukan baik melalui alat cetak maupun lisan yang dilakukan oleh pers. Delik pers termasuk dalam kejahatan melalui alat cetak. Dalam hal ini kejahatan dengan alat cetak dapat dilakukan oleh siapa pun (Loqman, 1996). Contoh kejahatan dengan alat cetak adalah kalender yang memuat unsur pornografi.

Upaya hukum tersebut sejalan dengan batasan-batasan yang merupakan rambu-rambu terhadap kebebasan pers dalam Convention on the Freedom of Information tahun 1985 di Roma. Pers yang libertarian sekalipun dalam substansi pemberitaannya tidak boleh bertentangan dengan atau memuat hal-hal sebagai berikut: (a) keamanan nasional dan ketertiban umum; (b) pemidanaan terhadap hasutan untuk menimbulkan kebencian ras atau agama; (c) hasutan untuk melakukan kejahatan atau kekerasan; (d) serangan terhadap pendiri agama yang menimbulkan pelanggaran terhadap delik blasphemy; (e) kesehatan dan moral; (f) hak-hak kehormatan dan nama baik seseorang yang umumnya memuat delik penghinaan; dan (g) umumnya menyangkut delik-delik yang bersangkutan dengan pengadilan kemudian suatu bentuk dari countempt of court (Adji, 2001).

Walaupun terdapat upaya hukum melalui gugatan perdata maupun membuat laporan polisi, kedua upaya hukum tersebut jarang atau bahkan tidak pernah dilakukan. Para tersangka atau terdakwa lebih fokus pada perkara tindak pidana korupsi yang sedang mereka hadapi menjadi salah satu alasan upaya hukum atas pemberitaan media cetak dan elektronik yang tidak proporsional dan mengandung penghakiman oleh pers tidak ditempuh, meskipun pemberitaan tersebut mengarah pada penghinaan dan pencemaran nama baik. Alasan lainnya adalah efektivitas dari upaya hukum dari kedua jalur tersebut yang memakan jangka waktu yang lama. Selain itu ada kecenderungan bahwa setiap upaya hukum yang diambil terhadap pemberitaan pers yang mengandung unsur-unsur penghinaan maupun pencemaran nama baik akan menjadi bumerang karena akan memperburuk citra dan pandangan masyarakat terhadap pihak yang memperkarakan hal tersebut.

\section{Memaksimalkan Peran Dewan Pers dalam Penegakan Asas Praduga Tidak Bersalah}

Dengan demikan, cara agar pers nasional kembali memberitakan suatu perkara tindak pidana korupsi yang sesuai dengan etika jurnalisme dan UU No. 40 Tahun 1999 dengan memberitakan suatu perkara tindak pidana korupsi dengan proporsi yang berimbang dan tidak melakukan penghakiman atas kesalahan tersangka atau terdakwa adalah dengan memaksimalkan peran Dewan Pers nasional dalam melakukan pengawasan terhadap pelaksanaan Kode Etik Jurnalistik sesuai dengan ketentuan Pasal 15 ayat (2) huruf c UU No. 40 Tahun 1999. Kode Etik Jurnalistiktelah mewajibkan bagi wartawanuntuk memberikan pemberitaan secara berimbang, tidak mencampuradukkan fakta dengan opini yang menghakimi, serta menerapkan asas praduga tidak bersalah. Lebih lanjut dalam tafsiran resmi Kode Etik Jurnalistik dijelaskan bahwa wartawan harus melakukan pengujian informasi dengan melakukan check dan recheck tentang kebenaran informasi tersebut. Wartawan juga harus memberikan perimbangan dalam memberikan ruang dan waktu pemberitaan kepada masing-masing pihak secara proporsional. Wartawan juga dilarang memberikan opini pribadi yang menghamiki. Hanya opini interpretatif atas fakta saja yang dipebolehkan. Dalam melakukan pemberitaan, wartawan 
juga harus berpegang pada asas praduga tidak bersalah yang tidak menghakimi seorang tersangka atau terdakwa.

Pengawasan atas Kode Etik Jurnalistik terutama mengenai penerapan asas praduga tidak bersalah inilah yang harus ditekankan oleh Dewan Pers. Hal ini akan menjadi pintu bagi pers nasional untuk dapat memberikan pemberitaan mengenai perkara tindak pidana korupsi dengan proporsional dan tidak menghakimi para tersangka atau terdakwa dengan percampuran antara fakta dan opini yang berkembang di media dan di masyarakat.Terlaksananya asas praduga tidak bersalah baik dalam pers maupun dalam hukum acara pidana akan memberikan jaminan bagi peradilan yang adil atau fair trial tersangka atau terdakwa yang merupakan hak-hak dasar mereka yang harus dilindungi (Huda, 2010). Pengawasan akan penerapan asas perduga tidak bersalah pun tidak berarti bahwa kebebasan pers di Indonesia dihalang-halangi. Penerapan asas praduga tak bersalah sama sekali tidak mengurangi pers untuk mengemukakan fakta. Pada prinsipnya pers tetap boleh mengemukakan semua fakta yang ada, kecuali yang jelas-jelas dinyatakan dilarang dalam dalam Kode Etik Jurnalistik. Pers merupakan "mata dan telinga" masyarakat akan fakta-fakta yang muncul selama proses penyidikan sampai dengan persidangan (Sukardi, 2010).

Selain itu dengan Dewan Pers juga harus membangun kesadaran pada pers nasional bahwa penegakan atas penerapan asas praduga tidak bersalah merupakan bagian dari fungsi pers untuk membangun kesadaran hukum masyarakat dan penghormatan atas supremasi hukum. Dewasa ini masyarakat Indonesia lebih percaya pada fakta-fakta dan opini yang dibangun oleh media massa, termasuk fakta-fakta dan opini terkait dengan suatu perkara tindak pidana korupsi. Apa yang dikemukan oleh media massa baik cetak maupun elektronik dipandang sebagai suatu kebenaran. Akibatnya, jika pada faktanya kemudian dalam persidangan Majelis Hakim memutus yang tidak sesuai dengan fakta-fakta dan opini yang telah disampaikan oleh media massa, masyarakat akan bereaksi negatif (Huda, 2010). Yang menjadi permasalahan adalah banyak dari fakta dan opini yang dibangun oleh media massa ditujukan untuk kepentingan politik tertentu, terutama menjelang pemilihan umum 2014. Dewan Pers harus mendorong Pers Nasional untuk memberikan pemberitaan yang cerdas dengan lebih banyak menghadirkan fakta-fakta dan menghindari opini yang didasarkan pada penafsiran dari ahli atau narasumber yang sepihak saja. Sudah saatnya menciptakan kesadaran bagi pers nasional bagi pers di Indonesia, tidak saja sebagai mata dan telinga rakyat sebagai kontrol sosial tetapi juga sebagai media untuk membangun kecerdasan bangsa dengan mengedepakankan asas praduga tidak bersalah melalui pemberitaan yang proporsional dan tidak melakukan penghakiman kepada tersangka, terdakwa, atau kelompok tertentu.

\section{Mendorong Pertanggungjawaban Pers Nasional kepada Masyarakat}

Pers nasional dewasa ini memang sudah sangat menganut paham libertarian dan ini menjadi permasalahan tersendiri karena meniciptakan kondisi yang tidak sehat bagi masyarakat Indonesia. Harus diakui bahwa banyak dari masyarakat Indonesia yang masih belum dapat memilah dengan baik mana pemberitaan yang baik yang tidak mengiring pada penciptaan opini yang sengaja dibuat oleh pemegang kepentingan dengan yang tidak. Bagitu pula dalam pemberitaan perkara-perkara tindak pidana korupsi. Hal ini tidak mustahil akan menciptakan ketidakpercayaan masyarakat pada sistem peradilan maupun kredibilitas dari aparat penegak hukum di Indonesia. Oleh karenanya pers nasional juga harus disadarkan pada tanggung jawab kepada masyarakat.

Menurut Theodore Peterson kebebasan pers terkandung suatu tanggung jawab yang sejajar yang memberikan kedudukan pers dalam posisi yang terhormat dalam suatu pemerintah. Lebih lanjut menurut Peterson, pers harus bertanggung jawab kepada masyarakat dengan mengetahui landasan operasional kerjanya sehingga dapat memuaskan masyarakat. Jika pers tidak mau menerima tanggung jawabnya, akan lebih baik ada institusi lain yang mengambil alih fungsi komunikasi pers tersebut. Hal ini berarti harus terdapat badan peradilan yang layak untuk menentukan ada atau tidaknya tanggung 
jawab terhadap isi pemberiaan dari pers. Pertanggungjawaban pers tersebut antara lain tercermin dari fungsi-fungsi pers sebagai berikut: (1) Melayani sistem politik dengan memberikan informasi, diskusi dan perbedayan terhadap masalah yang ada pada masyarakat; (2) Memberikan penerangan pada masyarakat, agar masyarakat dapat mengatur diri sendiri; (3) Menjaga hak-hak pribadi dengan bertindak sebagai pengawas terhadap pemerintah; (4) Melayani sistem ekonomi dengan mempertemukan pembeli dan penjual barang-barang atau jasa-jasa melalui iklan; (5) Menyediakan hiburan; dan (6) Mengupayakan sendiri biaya finansial sehingga bebas dari tekanan pihak yang memiliki kepentingan khusus (Adji, 2008).

Khusus dalam perkara tindak pidana korupsi, pers harus menjadi penghubung antara informasi yang disampaikan oleh aparat penegak hukum dengan tersangka atau terdakwa dalam setiap proses baik dari tingkat penyelidikan sampai dengan persidangan. Segala wawancara maupun diskusi dan dialog yang dilaksanakan semata-mata harus bertujuan untuk melayani masyarakat dengan memberikan fakta dan opini yang benar dan berimbang tanpa menghakimi salah satu pihak serta bukan untuk tujuan kepentingan politik atau ekonomi pemilik perusahaan pers tersebut. Pers dalam melakukan pemberitaan harus bertanggung jawab kepada masyarakat dengan memberikan informasi yang tidak melanggar hak-hak pribadi dari tersangka atau terdakwa yang pemberitaan tersebut harus mengedepankan asas praduga tidak bersalah, proporsionalitas dalam pemberitaan sehingga tidak menciptakan penghakiman yang didasarkan pada pembentukan opini publik yang negatif kepada para tersangka atau terdakwa.

Memaksimalkan peran Dewan Pers untuk melakukan pengawasan terhadap pelaksanaan Kode Etik Jurnalistik sesuai dengan ketentuan Pasal 15 ayat (2) huruf c UU No. 40 Tahun 1999 merupakan salah satu upaya untuk menuntut pertanggungjawaban pers atas segala pemberitaan kepada masyarakat. Melalui peran Dewan Pers ini pula diharapkan pers nasional dapat lebih memahami Kode Etik Jurnalistik sebagai landasan operasional mereka.

Kepedannya diperlukan peran lebih dari Dewan Pers. Berpedoman pada pendapat Peterson tersebut kiranya Dewan Pers dapat diberikan peranan lebih sebagai suatu lembaga peradilan profesi yang memiliki kewenangan untuk mengadili apakah suatu pemberitaan yang disampaikan oleh pers melanggar Kode Etik Jurnalistik dan kepentingan masyarakat. Hal ini seperti halnya yang Peradilan Profesi Advokat yang berada di bawah Dewan Kehormatan Persatuan Advokat Indonesia (Peradi). Tentunya hal ini bukan dimaksudkan untuk mengekang kebebasan pers melainkan lebih untuk memberikan perimbangan mengenai pertanggungjawaban pers terutama terhadap masyarakat. Keberadaan lembaga peradilan ini lebih dimaksudkan untuk meningkatkan profesionalitas wartawan dalam membuat pemberitaan. Melalui adanya lembaga peradilan profesi ini, wartawan diharapkan dapat menjalankan profesinya dengan menyajikan karya jurnalistik yang berpedoman pada Kode Etik Jurnalistik dan tidak dikendalikan oleh pemegang kepentingan baik politik atau ekonomi.

Meskipun demikian, hal tersebut merupakan suatu rencana jangka panjang. Hal ini disebabkan untuk membentuk lembaga peradilan profesi tersebut proses diperlukan landasan hukum pembentukannya terlebih dahulu. Paling tidak, harus dilakukan revisi atas UU No. 40 Tahun 1999 dengan memberikan memberikan wewenang tambahan kepada Dewan Pers untuk dapat melaksanakan kewenangan barunya yaitu untuk membentuk dewan kehormatan profesi pers dan memiliki kewenangan untuk melakukan peradilan atas pelanggaran Kode Etik Jurnalistik.

\section{SIMPULAN}

Berdasarkan pembahasan terhadap permasalahan-permasalahan hukum tersebut, disimpulkan sebagai berikut. Pertama, terjadi pergeseran mengenai kebebasan pers di Indonesia pascareformasi 1998. Pers nasional bergeser dari pers model soviet komunis yang lebih menitikberatkan pada 
tanggung jawab daripada kebebasan menjadi pers model libertarian yang lebih menitikberatkan pada kebebasan dari pada tanggung jawab. Kedua, persegersan pers nasional tersebut di satu sisi telah membawa dampak yang negatif. Pers nasional dewasa ini kerap menjadi corong dan alat politik pemilik modal yang juga menjadi petinggi partai peserta pemilihan umum 2014. Akibatnya banyak dari pemberitaan terutama pemberitaan terkait perkara tindak pidana korupsi yang mengabaikan asas praduga tidak bersalah dengan menghadirkan pemberitaan yang tidak proporsional dan mengadili kesalahan para tersangka, terdakwa, maupun kelompok tertentu dengan pembentukan opini-opini publik yang menghakimi. Ketiga, pers nasional yang menganut model libertarian memberikan ramburambu berupa batasan terhadap kebebasan pers. Pihak yang merasa disudutkan oleh pemberitaan pers memiliki hak jawab. Selain itu badan peradilan juga memiliki kewenangan untuk membatasi kebebasan pers nasional yang libertarian tersebut melalui gugatan perbuatan melawan hukum terkait pencemaran nama baik maupun delik-delik pers. Namun faktanya batasan-batasan tersebut dewasa ini tidak efektif untuk membendung kebebasan pers yang makin bebas.

Berdasarkan simpulan, berikut merupakan saran yang dapat menjadi solusi jangka pendek maupun jangka panjang terhadap permasalahan terkait kebebasan pers yang makin bebas dewasa ini. Pertama, perlunya Dewan Pers untuk berperan aktif dalam pengawasan pelaksanaan Kode Etik Jurnalistik sesuai dengan fungsi Dewan Pers dalam Pasal 15 ayat (2) huruf c UU No. 40 Tahun 1999. Salah satu pengawasan yang harus ditegakkan oleh Dewan Pers adalah penegakan atas pelaksanaan asas praduga tidak bersalah yang secara tegas telah diatur dalam Kode Etik Jurnalistik maupun dalam Pasal 5 ayat (1) UU No. 40 Tahun 1999. Kedua, Dewan Pers juga harus memaksimalkan fungsinya dalam peningkatan kehidupan pers nasional dengan membangun kesadaran pada pers nasional bahwa penegakan atas penerapan asas praduga tidak bersalah merupakan bagian dari fungsi pers untuk membangun kesadaran hukum masyarakat dan penghormatan atas supremasi hukum. Pers nasional harus menjadi salah satu sarana untuk mengedukasi masyarakat dengan memberikan pemberitaan yang baik dan berkualitas. Ketiga, sebagai suatu solusi jangka panjang, untuk menjaga indenpendesi wartawan sebagai motor pers nasional dari kepentigan ekonomi dan politik pemilik modal, maka kiranya dapat dibentuk suatu lembaga peradilan profesi pers yang memiliki kewenangan untuk menentukan pelanggaran atas Kode Etik Jurnalistik. Keberadan lembaga peradilan ini merupakan salah satu bentuk pertanggungjawab pers social terhadap masyarakat.

\section{DAFTAR PUSTAKA}

Adji, I. S. (2001). Kebebasan Pers: Tuntutan Kebebasan Absolut? Jakarta: Kantor Pengacara dan Konsultan Hukum Prof. Oemar Seno Adji, S.H. dan Rekan.

Adji, I. S. (2008). Hukum dan Kebebasan Pers. Jakarta: Diadit Media.

Adji, I. S., \& Adji, W. S. (1995). Pembatalan SIUPP sebagai Sengketa Tata Usaha. M. Elrick (Ed). Kapita Selekta Hukum Mengenang Almarhum Prof. H. Oemar Seno Adji, SH. Jakarta: Ghalia Indonesia. (hal. 254-262).

Adji, O. S. (1977). Mass Media dan Hukum. Jakarta: Erlangga.

Adji, O. S. (1977). Pers Aspek-Aspek Hukum. Jakarta: Erlangga.

Huda, C. (2010). Makna asas praduga tak bersalah dan pemakaiannya dalam praktek pers. Jurnal Dewan Pers. November 2010, (2), 33-44. 
Loqman, L. (1996). Percobaan, Penyertaan dan Gabungan Tindak Pidana. Jakarta: Universitas Tarumanega.

Loqman, L. (2010). Asas praduga tak bersalah di dalam pemberitaan oleh media massa. Jurnal Dewan Pers. November 2010, (2), 1-18.

Steele, J. (2013). Trial by the Press: an examination of journalism, ethicts, and islam in Indonesia and Malaysia. The International Journal of Press/Politics, 18(3), 342-359.

Sukardi, W. A. (2010). Menghindari tuduhan pelanggaran asas praduga tidak bersalah. Jurnal Dewan Pers. November 2010, (2), 19-32. 